\title{
In vitro Comparative Study on the Marginal Adaptation of Direct, Semi-direct and Indirect Composite Resins Restorations to Dentine and Dental Cementum
}

\begin{abstract}
CRISTINA HODOBET, ANNA MARIA PANGICA*, ANAMARIA FLORESCU, VIOLETA HANCU, FLORENTINA CO RNELIA BICLESANU
Titu Maiorescu University of Bucharest, Faculty of Dentistry, Department of Dental Specialities, 67A Gheorghe Petrascu Str., 031593, Bucharest, Romania

The aim of the present study is to compare the marginal adaptation of direct, semi-direct and indirect restorations made with nanofill and microhybrid composite materials and ormocers materials bonded with SE adhesives at the dentin and cementum. 120 standardized class II cavities were prepared (40 for each techniques- RD, RSD, RI) with the gingival margin over and below to the cementum-enamel junction. The teeth $(n=20)$ were restored using one of three adhesive systems (OptiBond XTR, G-Premio Bond bottle refill, Futurabond $U$ ) with incrementally placed composite restorations and ormocers. After applying the various restorations, the teeth were prepared for SEM analysis to check the marginal adaptation by the presence of continuous margins or gaps. Comparative analysis of treatment methods and materials used was performed by statistical analysis of Chi-square test data, the statistical significance was $p<0.05$ and Fisher's Exact Test for validation of results. It was found that among the three materials used for RD, RSD, RI both at the dentin and the cementum, there are no significant differences $(R D d=0.661, R S D / d=0.755$, $R S D / C=0.942 ; R I / d=0.739 ; R I / C=0.985)$. Comparison between the presence of continuous margins/gaps subgingivally and supragingivally at the three types of restorations shows that there are significant differences between the marginal adaptation at the cementum and dentin to all the restoration techniques used ( $p$ $<0.05)$. Directand indirect restorations with nanocomposites and ormocers bonded with 1-step SE adhesive are the best solutions for restoring the posterior teeth.
\end{abstract}

Keywords: direct restorations, indirect restorations, semi-direct restorations, inlay, marginal adaptation

The use of aesthetic restorations in the posterior dental area is already a standard procedure. The materials used are composite and ceramic resins and the techniques used are direct (RD), semidirect (RSD) and indirect (RI) restorations.

The direct adhesive technique in the posterior area is used for restoring small and medium sized cavities, but for large sized cavities. indirect techniques are recommended.

Indirect techniques show a number of advantages in terms of reducing the polymerization shrinkage that occurs only at the cementing resin level, the ability to achieve an interdental contact point and a more accurate anatomical modeling, and thus a very rigorous marginal adaptation. Marginal adaptation is a criterion for appreciating the longevity of a restoration. This reduces the possibility of mikroleakage and, ultimately, marginal discolorations, secondary caries or postoperative sensitivity.

Other important advantages in using indirect restoration are increasing bond strength, increasing surface hardness and reducing the risk of fractures and cracks in the internal structure of the material [1].

Semidirectrestorations are made by applying and curing the resin into the cavity, then they are subjected to heat treatment and light outside the oral cavity.

Direct inlays are achieved by lightcuring the composite in the prepared dental cavity, then extracuring outside the oral cavity, indirect inlays are obtained after an impression of the preparation.

Indirectcomposites represent an alternative to posterior teeth ceramic restorations, especially to prevent the occurrence of the abrasion phenomenon of the antagonist teeth determined by this material.

A new generation of composites is classified by Touati quoted by Torabzadeh H et al. 2013 as second-generation

*email:amipangica@yahoo.com; Phone:0722211147

3138

http://www revistadechimie.ro laboratory composites or optimized ceramic polymers (Ceromeri) [2].

Manufacturers and research data claim that they offer improved bending strength, increased elasticity, and fracture resistance as compared to direct composites [2].

The aim of this study is to evaluate the marginal adaptation of direct, semidirect and indirect restorations made with nano composite filling materials (Premise ${ }^{T M}$, Estelite Sigma Quick), microhybrid composite (Gradia direct), ceromers (Crea.ling Bredent, Ceramage Shofu ArtGlace, Hereus) and ormocer (Admira Fusion) bonded with 2-step self-etch adhesive systems (OptiBond XTR) and 1-step self etch (G-Premio Bond bottle refill) and dual cure cement (Futurabond $\mathrm{U}$ ) at the dentin and cementum.

\section{Experimental part}

The study included 60 extracted teeth collected from anonymous patients. Prior to the treatment, patients were informed about the use of teeth in research studies and gave their consent to the use of biological material for research purposes.

The teeth were cleaned and disinfected to a short sterilization cycle in the autoclave and then rehydrated for 48 hours in physiological saline solution. The teeth were divided into 3 groups of 20 teeth each which were prepared with standardized 2nd class cavities on both proximal surfaces, in order to be restored through direct restorations (group 1 RD) and semidirect (group 2 RSD) and indirect (group $3 \mathrm{RI}$ ) as follows: on the distal surfaces the gingival extension was $1 \mathrm{~mm}$ above the enamel-cementum junction, on the mesial surfaces, $1 \mathrm{~mm}$ below it.

The restorations were made with composite resins and adhesive systems according to table 1 .

Prior to application of the adhesive, the dental structures were treated with $37 \%$ phosphoric acid by total etching technique.

REV.CHIM. (Bucharest) $\bullet 69$ No. $11 \bullet 2018$ 
Table 1

COMPONENT OF STUDY BATCHES

\begin{tabular}{|c|c|c|c|c|c|}
\hline \multicolumn{2}{|c|}{ Batch 1RD } & \multicolumn{2}{|c|}{ Batch 2 RSD } & \multicolumn{2}{|c|}{ Batch 3RI } \\
\hline Composite & Adhesive & Composite & Adhesive & Composite & Adhesive \\
\hline Premise ${ }^{\mathrm{IM}}$ & G-Premio Bond & Admira Fusion & Futurabond U & $\begin{array}{l}\text { Ceramage } \\
\text { Shofu }\end{array}$ & $\begin{array}{l}\text { Adhese Universal viva } \\
\text { Pen, Ivoclar }\end{array}$ \\
\hline Gradia direct & OptiBond XTR & Premise & OptiBond XTR & $\begin{array}{l}\text { Crea.ling } \\
\text { Bredent }\end{array}$ & $\begin{array}{l}\text { Adhese Universal viva } \\
\text { Pen, Ivoclar }\end{array}$ \\
\hline Admira Fusion & Futurabond U & ESTELITE & G-Premio Bond & $\begin{array}{l}\text { Art Glass } \\
\text { Hereus }\end{array}$ & $\begin{array}{l}\text { Adhese Universal viva } \\
\text { Pen, Ivoclar }\end{array}$ \\
\hline
\end{tabular}

Ine materials used tor the study and their composition are presented in table 2 .

After applying different restorations, by means of a high speed diamond bur and under cooling, mesial and distal aspects of the teeth were prepared such that flat surface exposure of the preparation, restorations and the area between restoration and dental structures could be seen and examined.

The exposed area was polished with plastic discs and soft discs for better exposure for SEM analysis.
The teeth were prepared tor SEM analysis by exposing them to a gold spraying system. Using a mini-gold sprayer, gold is sprayed for 30 seconds at a pressure of $\sim 70$ mTorr. A different thickness of the gold layer may be required depending on the geometry of the sample. Coarser or porous surfaces require a longer spraying time (fig.1).

The analysis of the marginal adaptation was performed using the Quanta Inspect F electronic microscope equipped with field emission gun (FEM) with a resolution of $1.2 \mathrm{~nm}$ and an energy dispersive $X$-ray spectrometer (EDS ) with a resolution of $133 \mathrm{eV}$ MnK (fig. 2).

\begin{tabular}{|c|c|}
\hline Material & Composition \\
\hline Premise ${ }^{\mathrm{TM}}, \mathrm{Kerr}$ & $\begin{array}{l}\text { Bis-GMA } \\
\text { Filling } 69 \%, 84 \% \text { wt: } \\
\text { Silica nanoparticles } 0.02 \mu \text {, prepolymerized filler } 30-50 \mu \text {, sticlă of barium of } 0,4 \\
\text { microns }\end{array}$ \\
\hline $\begin{array}{l}\text { OptiBond XTR Kerr, } \\
\text { universal }\end{array}$ & $\begin{array}{l}\text { Ethyl alcohol } 20-30 \% \\
\text { Alkyldimethacrylate } 47-68 \% \\
\text { barium aluminoborosilicate glass } 5-15 \% \text { silicon dioxide (silicon dioxide) } 3-10 \% \\
\text { sodium hexafluorosilicate } 0.5-3 \%\end{array}$ \\
\hline $\begin{array}{l}\text { Gradia direct, Denta } \\
\text { Products Corp, Tokyo, } \\
\text { Japan }\end{array}$ & $\begin{array}{l}\text { Matrix: urethane dimethacrylate (UDMA) } 20-25 \% \\
\text { Ethylene dimethacrylate } \\
\text { Filling: } 65 \% \text { volume } \\
\text { Silica, pre-polymerized particles, flour-alumino-silicate glass }\end{array}$ \\
\hline $\begin{array}{l}\text { Admira Fusion, Voco } \\
\mathrm{GmbH} \text {, Cuxhaven, Germany }\end{array}$ & $\begin{array}{l}\text { Matrix: Ormocer resin } \\
\text { Filling: silicon oxide nano filler, glass ceramics filler }(1 \mu \mathrm{m})\end{array}$ \\
\hline $\begin{array}{l}\text { Futurabond U } \\
\text { Voco GmbH, } \\
\text { Cuxhaven, Germany }\end{array}$ & $\begin{array}{l}\text { Liquid 1: 2-hydroxyethyl methacrylate monomers }(10-25 \%) \text { (HEMA), BIS- } \\
\text { GMA (10-25\%), Urethanedimethacrylate }(2.5-5 \%) \text { (UDMA) } \\
\text { Liquid 2: Ethanol (10-25\%), initiator, catalyst, silicic pyrogenic acid }(2.5-5 \%) \text {. }\end{array}$ \\
\hline $\begin{array}{l}\text { Variolink Esthetic DC } \\
\text { Ivoclar Vivadent }\end{array}$ & $\begin{array}{l}\text { Matrix: Bis-GMA, dimethacrylate urethane, glycyl dimethacrylate } \\
\text { Filler }(0.04-3.0 \mu \mathrm{m} \text {, average particle size } 0.7 \mu \mathrm{m} \text {.) } \\
\text {-yterbium trifluoride, barium glass, Ba-Al-fluorosilicate glass beads } \\
\text {-catalysts, stabilizers and pigments. }\end{array}$ \\
\hline $\begin{array}{l}\text { G-Premio Bond bottle refill, } \\
\text { GC, Japonia }\end{array}$ & $\begin{array}{l}\text { Acetone }(25-50 \%), 2 \text {-hydroxy-1,3-dimethacrylaxypropane }(10-20 \%) \text {, } \\
\text { methacryloyloxydecyl dihydrogen phosphate }(5-10 \%), 2,2 \text { - } \\
\text { ethylenedioxydiethyl dimethacrylate }(1-5 \%) \text {, diphenyl }(2,4,6 \text {-trimethylbenzoyl }) \\
\text { phosphine oxide }(1-5 \%), 2,6 \text {-di-tert-butyl-p-cresol }(<0.5 \%) \text {. }\end{array}$ \\
\hline $\begin{array}{l}\text { Crea.lign } \\
\text { Bredent } \mathrm{GmbH} \& \mathrm{Co} . \mathrm{KG}\end{array}$ & $\begin{array}{l}\text { pure nano-composite which does not contain glass filling } \\
\text { tetramethylene dimethacrylate } \\
\text { 2-propenoic acid reaction products with pentaerythritol (PETIA / PETTA), } \\
\text { diphenyl }(2,4,6 \text {-trimethylbenzoyl) -phosphine oxide (TPO) } \\
7,7,9 \text { (or } 7,9,9) \text {-trimethyl-4,13-dioxo-3,14-dioxa-5,12-diazahexadecane-1,16-diyl } \\
\text { bismethacrylate }(25-50 \%) \\
\text { tetramethylene dimethacrylate (10-25\%), inorganic fillers, initiators and } \\
\text { colorants }\end{array}$ \\
\hline $\begin{array}{l}\text { Ceramage } \\
\text { Shofu, }\end{array}$ & $\begin{array}{l}\text { Matrix } \\
\text { UDMA, 2-HEMA, urethane diacrylate } \\
\text { Filling } 73 \% \\
\text { zirconium silicate (PFS-progressive fine structured filler) pigment, } \\
\text { photoinitiator, zirconium silicate. }\end{array}$ \\
\hline ArtGlass Hereus & $\begin{array}{l}\text { Matrix - 30\% organic resin (bis DMA, TEGMA.) In addition to conventional } \\
\text { bifunctional molecules, Artglass contains four to six functional groups which } \\
\text { offer the possibility of multiple conversions with double photoinitiator bindings. } \\
\text { Filling - filling of } 70 \% \text { by weight of siliconized barium-siliconized aluminum } \\
\text { silicon } 0.7 \mu \mathrm{m} \text {, silicon dioxide. [11] }\end{array}$ \\
\hline
\end{tabular}

Table 2

MATERIALSAND APPLICATION TECHNIQUE USED IN THE STUDY 


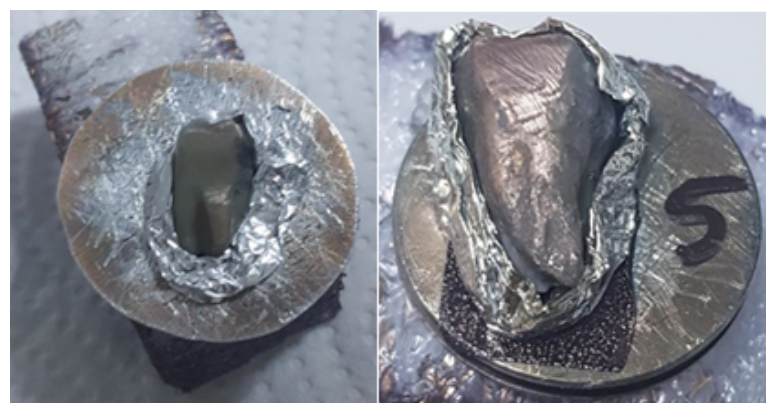

Fig.1 Exposure of the teeth to the mini-gold sprayer 3.

The final scheme of the study protocol is shown in figure

SEM analysis of marginal adaptation was performed using the following criteria:

- Continuous margins when there is no space between the restoration material and the dental structures;

- The presence of voids/gaps when there is space between the restoration material and the dental structures.

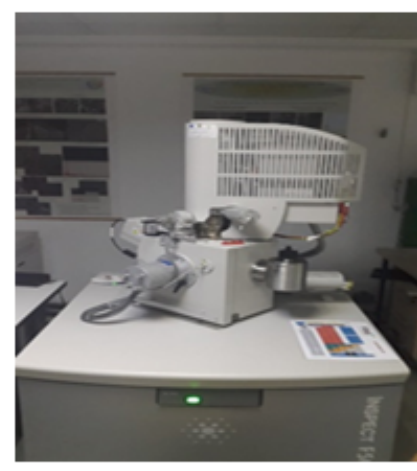

Statistical analysis

The data were analyzed using the SPSS statistical program package (IBM SPSS 20.0, SPSS Inc., Chicago, IL, USA). Descriptive and of distributions frequency statistics were used to compare the incidence of gaps of dental structure (dentine, cementum) - restoration material interfaces for the three restoration techniques (RD, RSD, $\mathrm{RI})$.

Comparative analysis of treatment methods and materials used was performed by statistical analysis of Chi-square test, the statistical significance was $p<0.05$ and Fisher's Exact Test for validation of results.
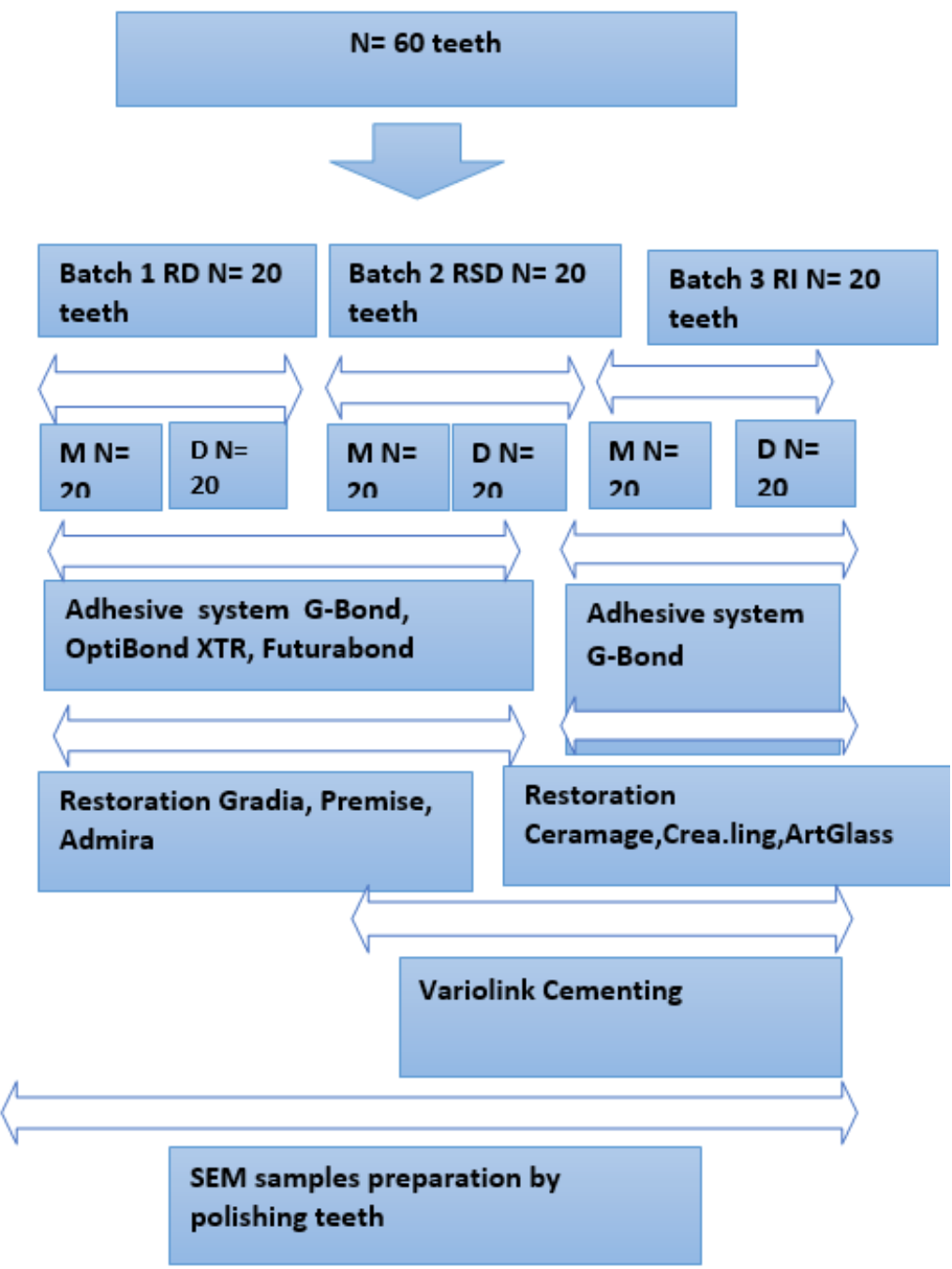

Fig. 3.

SEM samples preparation 


\section{Results and discussions}

According to the established criteria (continuous margins, gaps), the SEM analysis of the restoration/dentin/cementum interfaces of the three groups is presented in the following figures (figs. 4-9)

Group RD

Below CEJ

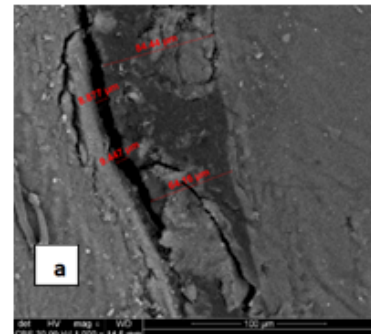

\section{AboveCE]}
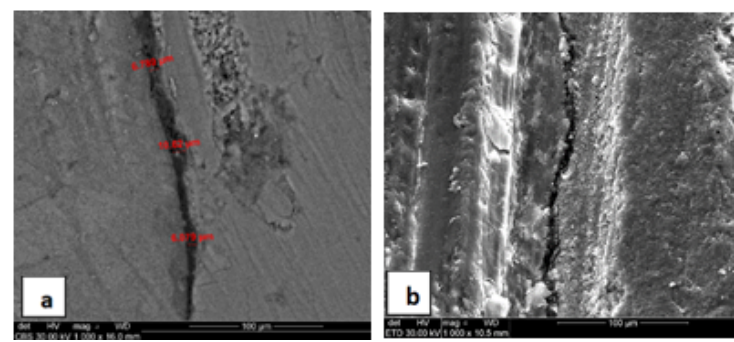

Group 2RSD

Below CEJ
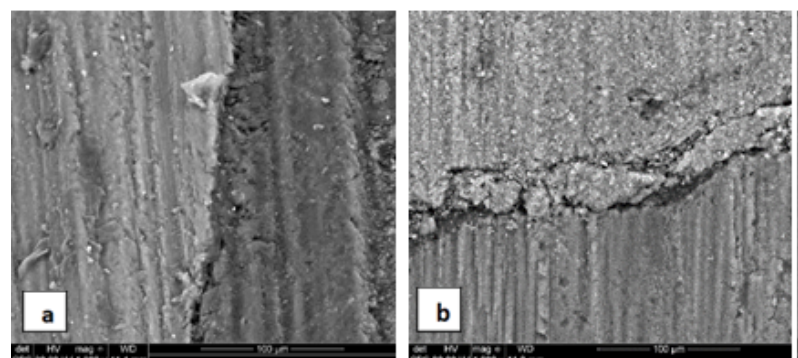

Above CEJ

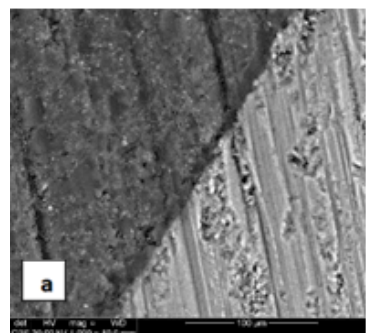

Group Rl

Below CEJ
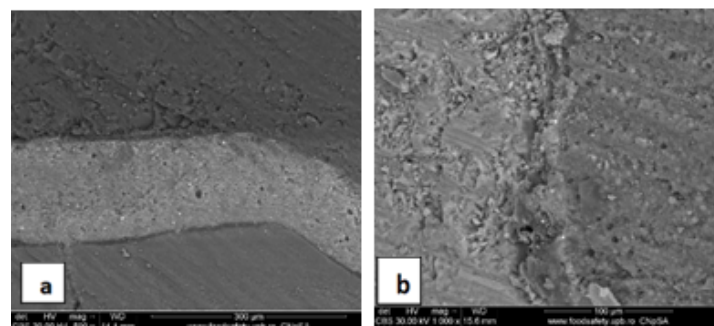

Above CEJ
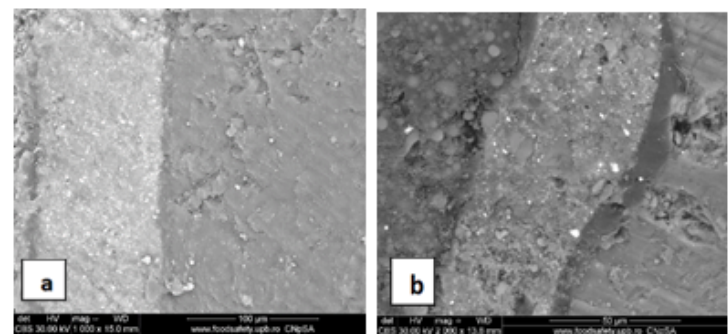
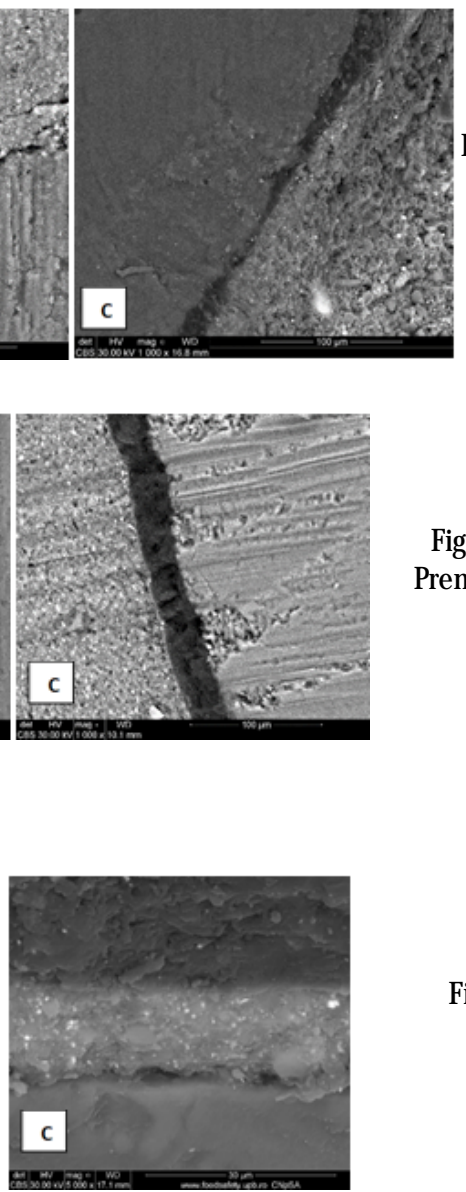
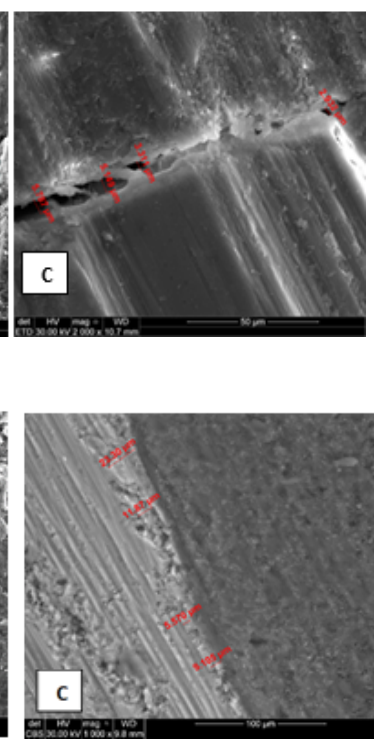

Fig.5. a. Premise Kerr/ G-Premio Bond; b. Gradia direct / OptiBond XTR; c. Admira Fusion/ Futurabond

Fig. 6a. Estelite / G-Premio Bond/Variolink; b. Premise Kerr/ OptiBond XTR; c. Admira Fusion/ Futurabond $U$

ig.4a Premise Kerr/ G-Premio Bond; b. Gradia Futurabond $U$
Fig.7a. Estelite / G-Premio Bond/ Variolink; b. Premise Kerr/ OptiBond XTR; c. Admira Fusion/ Futurabond $U$

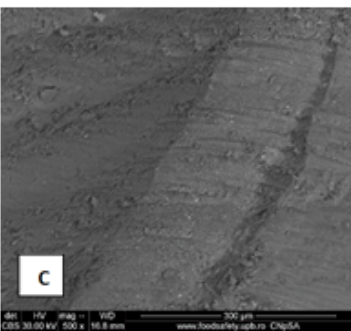

Fig. 8a. Artglass; b. Ceramage; c. Bredent

Fig.9a. Artglass; b. Ceramage; c. Bredent

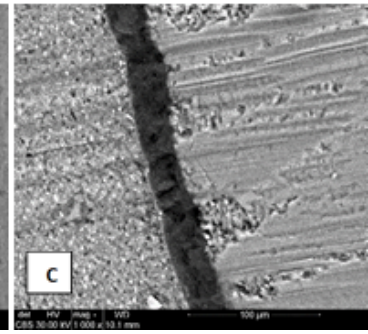


We calculated the mean and standard deviation to compare the materials used according to established criteria (continuous margins, presence of gaps). It was found that among the three materials used for RD, RSD, RI at both the dentin and the cementum, there are no significant differences (RD/d $=0.661, \mathrm{RSD} / \mathrm{d}=0.755, \mathrm{RSD} /$ $c=0.942 ; \mathrm{RI} / \mathrm{d}=0.739 ; \mathrm{RI} / \mathrm{c}=0.985)$.

We then used mean and standard deviation to compare the restoration techniques used.

Below CEJ

\begin{tabular}{|c|c|c|c|c|}
\hline & Mean & $\begin{array}{c}\text { Std. } \\
\text { Deviation }\end{array}$ & $\begin{array}{l}\text { Std. } \\
\text { Error }\end{array}$ & $\begin{array}{c}\mathrm{p}- \\
\text { value }\end{array}$ \\
\hline RD & $10 \%$ & 0.308 & 0.069 & 0.116 \\
\hline RSD & $15 \%$ & 0.366 & 0.082 & \\
\hline Rा & $35 \%$ & 0.489 & 0.109 & \\
\hline
\end{tabular}

\section{Above CEJ}

\begin{tabular}{|l|r|r|r|r|}
\hline & Mean & $\begin{array}{c}\text { Std. } \\
\text { Deviation }\end{array}$ & $\begin{array}{c}\text { Std. } \\
\text { Error }\end{array}$ & $\begin{array}{c}\text { p- } \\
\text { value }\end{array}$ \\
\hline RD & $65 \%$ & 0.489 & 0.109 & 0.428 \\
\hline RSD & $55 \%$ & 0.510 & 0.114 & \multirow{2}{*}{} \\
\cline { 1 - 4 } RI & $75 \%$ & 0.444 & 0.099 & \multicolumn{1}{|c|}{} \\
\cline { 1 - 4 } & & &
\end{tabular}

$p>0.05$ there are no significant differences among the three restoration techniques.

Comparing the media among the restoration techniques, it has been pointed out the absence of significant differences. Comparison of areas with gaps was done with the Pearson Chi-Square test and for validation, Fisher's Exact Test.

Below CEJ

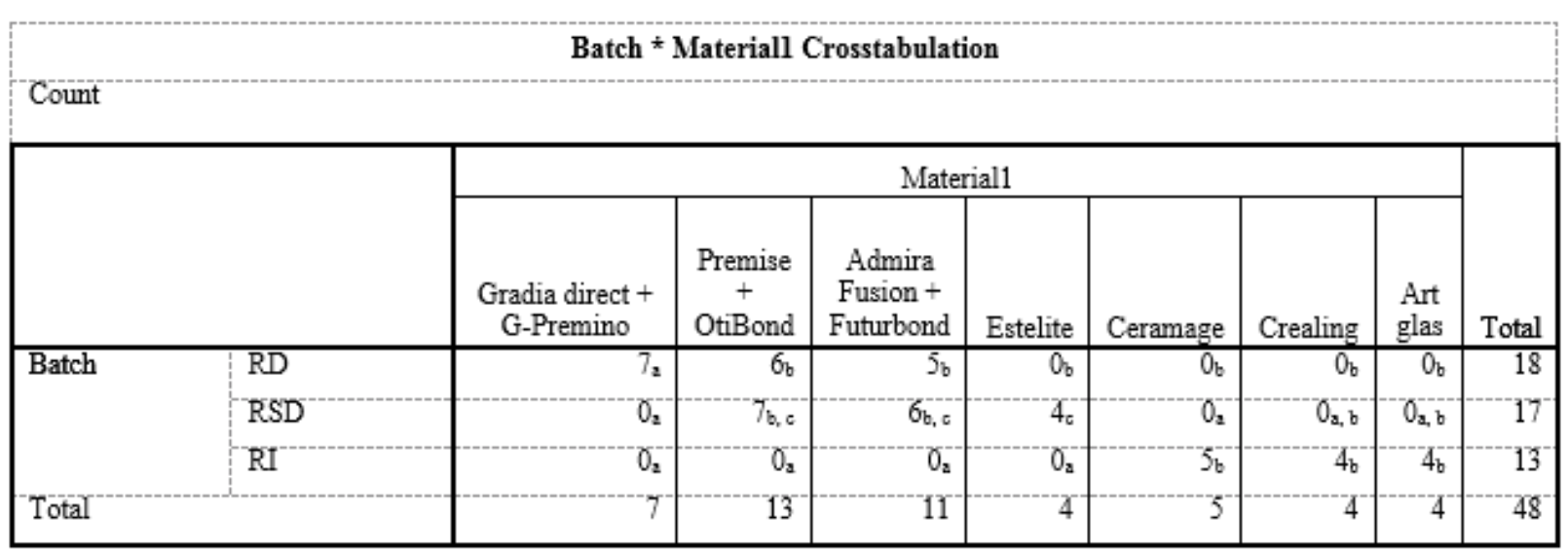

Each subscript letter denotes a subset of Material1 categories whose column proportions do not differ significantly from each other at the .05 level.

\section{Chi-Square Tests}

\begin{tabular}{|c|c|c|c|c|c|c|}
\hline & Value & df & $\begin{array}{l}\text { Asymp. } \\
\text { Sig. (2- } \\
\text { sided) }\end{array}$ & $\begin{array}{l}\text { Exact Sig. } \\
\text { (2-sided) }\end{array}$ & $\begin{array}{l}\text { Exact Sig. } \\
\text { (1-sided) }\end{array}$ & $\begin{array}{c}\text { Point } \\
\text { Probability }\end{array}$ \\
\hline Pearson Chi-Square & $63.289^{\mathrm{a}}$ & $\overline{12}$ & .000 & .000 & & \\
\hline Likelihood Ratio & 71.461 & 12 & .000 & .000 & & \\
\hline Fisher's Exact Test & 49.560 & & & .000 & & \\
\hline $\begin{array}{l}\text { Linear-by-Linear } \\
\text { Association }\end{array}$ & $34.125^{6}$ & 1 & .000 & .000 & .000 & .000 \\
\hline Nof Valid Cases & 48 & & & & & \\
\hline
\end{tabular}

a. 21 cells $(100.0 \%)$ have expected count less than 5 . The minimum expected count is 1.08 .

b. The standardized statistic is 5.842 .

\section{Above CEJ}

\begin{tabular}{|c|c|c|c|c|c|c|c|c|c|}
\hline \multicolumn{10}{|c|}{ Batch* Materiall Crosstabulation } \\
\hline & & \multicolumn{7}{|c|}{ Materiall } & \multirow[b]{2}{*}{ Total } \\
\hline & & $\begin{array}{c}\text { Gradia direct + G- } \\
\text { Premino }\end{array}$ & $\begin{array}{c}\text { Premise } \\
+ \\
\text { OtiBond }\end{array}$ & $\begin{array}{c}\text { Admira } \\
\text { Fusion + } \\
\text { Futurbond }\end{array}$ & Estelite & Ceramage & Crealing & $\begin{array}{c}\text { Mat } \\
\mathrm{x}\end{array}$ & \\
\hline \multirow[t]{3}{*}{ Lot } & $\mathrm{RD}$ & 3 & 2 & 2 & 0 & 0 & 0 & 0 & 7 \\
\hline & RSD & 0 & 2 & 4 & 3 & 0 & 0 & 0 & 9 \\
\hline & $\mathrm{RI}$ & 0 & 0 & 0 & 0 & $\bar{l}$ & 2 & 2 & 5 \\
\hline \multicolumn{2}{|c|}{ Total } & 3 & 4 & 6 & 3 & $\overline{1}$ & 2 & 2 & $2 \mathrm{l}$ \\
\hline
\end{tabular}




\begin{tabular}{|c|c|c|c|c|c|c|}
\hline \multicolumn{7}{|c|}{ Chi-Square Tests } \\
\hline & Value & df & $\begin{array}{l}\text { Asymp. } \\
\text { Sig. (2- } \\
\text { sided) }\end{array}$ & $\begin{array}{l}\text { Exact Sig. } \\
\text { (2-sided) }\end{array}$ & $\begin{array}{l}\text { Exact Sig. } \\
\text { (1-sided) }\end{array}$ & $\begin{array}{c}\text { Point } \\
\text { Probability }\end{array}$ \\
\hline $\begin{array}{l}\text { Pearson Chi- } \\
\text { Square }\end{array}$ & $29.556^{\mathrm{a}}$ & 12 & .003 & .000 & & \\
\hline Likelihood Ratio & 31.799 & 12 & .001 & .001 & & \\
\hline Fisher's Exact Test & 20.329 & & & .001 & & \\
\hline $\begin{array}{l}\text { Linear-by-Linear } \\
\text { Association }\end{array}$ & $15.134^{6}$ & 1 & .000 & .000 & .000 & .000 \\
\hline $\mathrm{N}$ of Valid Cases & 21 & & & & & \\
\hline
\end{tabular}

Both at dentine and cementum level, there are significant used shows that there is no association among them, so differences among the materials used $(p<0.05)$.

The comparison between the continuous margins/gaps supra and subgingivally at the three types of restoration there are significant differences among the marginal adaptation at cementum and dentine level in all the restoration techniques used.

\begin{tabular}{|c|c|c|c|c|c|c|c|}
\hline \multicolumn{8}{|c|}{ Chi-Square Tests } \\
\hline Lot & & Value & df & $\begin{array}{c}\text { Asymptotic } \\
\text { Significance } \\
\text { (2-sided) }\end{array}$ & $\begin{array}{l}\text { Exact Sig. } \\
\text { (2-sided) }\end{array}$ & $\begin{array}{l}\text { Exact Sig. } \\
\text { (1-sided) }\end{array}$ & $\begin{array}{c}\text { Point } \\
\text { Probability }\end{array}$ \\
\hline \multirow[t]{6}{*}{$\overline{\mathrm{RD}}$} & $\begin{array}{l}\text { Pearson Chi- } \\
\text { Square }\end{array}$ & $12.907^{\mathrm{d}}$ & 1 & 0.000 & 0.001 & 0.000 & \\
\hline & $\begin{array}{l}\text { Continuity } \\
\text { Correction }^{b}\end{array}$ & 10.667 & 1 & 0.001 & & & \\
\hline & Likelihood Ratio & 14.024 & 1 & 0.000 & 0.001 & 0.000 & \\
\hline & Fisher s Exact Test & & & & 0.001 & 0.000 & \\
\hline & $\begin{array}{l}\text { Linear-by-Linear } \\
\text { Association }\end{array}$ & $12.584^{\circ-}$ & 1 & 0.000 & 0.001 & 0.000 & 0.000 \\
\hline & Nof Valid Cases & 40 & & & & & \\
\hline \multirow[t]{6}{*}{ RSD } & $\begin{array}{l}\text { Pearson Chi- } \\
\text { Square }\end{array}$ & $6.833^{7}$ & 1 & 0.008 & 0.019 & 0.009 & \\
\hline & $\begin{array}{l}\text { Continuity } \\
\text { Correction }^{b}\end{array}$ & 5.385 & 1 & 0.020 & & & \\
\hline & Likelihood Ratio & 7.362 & 1 & 0.007 & 0.019 & 0.009 & \\
\hline & Fisher's Exact Test & & & & 0.019 & 0.009 & \\
\hline & $\begin{array}{l}\text { Linear-by-Linear } \\
\text { Association }\end{array}$ & $6.857 \mathrm{~s}$ & 1 & 0.009 & 0.019 & 0.009 & 0.008 \\
\hline & Nof Valid Cases & $40^{-}$ & & & & & \\
\hline \multirow[t]{6}{*}{ RI } & $\begin{array}{l}\text { Pearson Chi- } \\
\text { Square }\end{array}$ & $6.465^{\mathrm{h}}$ & 1 & 0.011 & 0.025 & 0.012 & \\
\hline & $\begin{array}{l}\text { Continuity } \\
\text { Correction }^{b}\end{array}$ & $4.949^{\circ}$ & 1 & 0.026 & & & \\
\hline & Likelihood Ratio & $-6.660^{-}$ & 1 & 0.010 & 0.025 & 0.012 & \\
\hline & Fisher's Exact Test & & & & 0.025 & 0.012 & \\
\hline & $\begin{array}{l}\text { Linear-by-Linear } \\
\text { Association }\end{array}$ & $6.303^{1}$ & 1 & 0.012 & 0.025 & 0.012 & 0.011 \\
\hline & $N$ of Valid Cases & $40^{-}$ & & & & & \\
\hline \multirow[t]{6}{*}{ Total } & $\begin{array}{l}\text { Pearson Chi- } \\
\text { Square }\end{array}$ & $24.859^{\mathrm{a}}$ & 1 & 0.000 & 0.000 & 0.000 & \\
\hline & $\begin{array}{l}\text { Continuity } \\
\text { Correction }\end{array}$ & 23.052 & 1 & 0.000 & & & \\
\hline & Likelihood Ratio & 25.903 & 1 & 0.000 & 0.000 & 0.000 & \\
\hline & Fisher's Exact Test & & & & 0.000 & 0.000 & \\
\hline & $\begin{array}{l}\text { Linear-by-Linear } \\
\text { Association }\end{array}$ & $24.652^{\mathrm{c}}$ & 1 & 0.000 & 0.000 & 0.000 & 0.000 \\
\hline & N of Valid Cases & 120 & & & & & \\
\hline
\end{tabular}

a. 0 cells $(0.0 \%)$ have expected count less than 5 . The minimum expected count is $25.50 ; \mathrm{b}$. Computed only for a $2 \times 2$ table;

c. The standardized statistic is 4.965; $\mathrm{d}$. 0 cells $(0.0 \%)$ have expected count less than 5 . The minimum expected count is $7.50 ;$ e. The standardized statistic is $3.547 ;$ f. 0 cells $(0.0 \%)$ have expected count less than 5 . The minimum expected count is 7.00 . g. The standardized statistic is 2.619 . h. 0 cells

$(0.0 \%)$ have expected count less than 5. The minimum expected count is 9.00. i. The standardized statistic is 2.511. 
In this study we analyzed through SEM the integrity and marginal adaptation of some restorations made with composite resins by direct, semi-direct and indirect techniques. SEM analysis is the most efficient method for determining gaps and, therefore, appreciating the continuity of tooth - restoration material interfaces.

The root cementum has so far been much less studied than other dental structures in terms of adhesion. Perhaps for this reason, at least nowadays, not only are there fewer things known about this subject, but the results obtained are not so clear. Root cementum has properties closer to dentin, but with a different physico-chemical structure [3].

Correa Netto et al. [4] and Shim et al. [5] reported in their studies that the success of direct and indirect restorations depends on several factors, one of the most important being marginal adaptation.

In this study, a significant difference was observed between the marginal adaptation for gingival limit restorations in cementum/dentin as compared to dentinal gingival restorations. $(p<0.005)$.

Araujo et al. and Tredwin et al. quoted by Dhingra V. [6] reported that cementum/dentine edge restorations have significantly microleakage than those with enamel location. This difference can be explained by the structure of substrates, dentin and cementum have a greater proportion of water and organic material than enamel, which makes it difficult to obtain an adhesive capable of resisting the adverse effects of polymerization shrinkage, thermal stress.

In this study we used self-etching adhesive systems, one step G-Premio BOND and self-etch, 2 steps OptiBond XTR. Compared to ER adhesive systems, SE adhesive systems have some advantages over the lack of acid scaling as a separate step, so washing and drying after demineralization is eliminated, and clinical efficiency is improved by reducing working time. Elimination of washing and drying phases presents another advantage related to the elimination of postoperative sensitivityassociated with adhesion to demineralized dehydrated dentine [7].

These properties may explain, at least in part, the result that SE adhesive systems produce a larger continuous interface. Self-etching systems use different acid primers to alter and/or solubilize the smear layer, and although it does not wash, as in the case of total etch systems, direct interaction of the dentine substrate adhesive is achieved [8].

To enhance the wetting, spreading and penetration of the polymerizable monomers in the dentine, different solvents are used as thinning agents. These solvents are typically water, ethyl alcohol, butyl alcohol or acetone. The first three are very hydrophilic and thus increase the interaction of monomers with surface water, while acetone assures the displacement of water inside the dentin. Thus, this solvent is incorporated into the hybrid layer and can be a contamination factor that can cause the adhesion to weaken. The monomers in dental adhesives are similar to those used in dental composites, thus ensuring a strong interaction between the adhesive and the composite [8].

In this study we used an adhesive system containing ethanol (G-Premio Bond bottle refill) and one with acetone as solvent (Optibond XTR). The results obtained showed that RD made with Premise (universal nanoparticles with trimodal and prepolymerized particles) and G-Premio Bond bottle refill showed at the level of the cement a relatively uneven adhesive layer with an average thickness of $70 \mathrm{im}$ and the presence of the gaps of approx. 9im, while the combination of Gradia and Optibond XTR showed larger goals, of approx. $20 \mu \mathrm{m}$. Kurtzman GM shows that Premise
Restoration through G-Premio Bond forms a thin layer of adhesive which reduces the number of gaps [9]. At the dentine level there were no gaps and the thickness of the adhesive layer was on average $8 \mu \mathrm{m}$.

Recently, some manufacturers have introduced universal adhesives that can be used with self-etching and etch and rinse techniques, selective or total etch techniques [10]. In this study, the association between Admira Fusion and Futurabond U (Voco) (8th generation universal bonding agent containing nanomaterials) determined the presence of small sized gap areas $(2.93-5.78 \mu \mathrm{m})$ and at the level of the dentin the presence of a very good adhesion without gaps.

Most of the internal gaps in the current study were observed at axiopulpal line angles. This finding agrees with those of Souza-J unior et al. [11].

Teeth with indirect restorations are potentially less susceptible to deterioration than those with direct restorations.

Composite inlays provide better sealing compared to direct restorations [12].

The polymerization shrinkage determines the level of stress in teeth with direct restorations, while its impact on adherence to indirectly restored teeth is insignificant.

At RSD and RI, the larger the marginal gaps, the higher the dissolution rate of the cement. Although rarely clinically achieved, the ideal size of marginal gaps should be 25-40 $\mu \mathrm{m}$ [13].

However, the statistical analysis showed that among the three materials used for RD, RSD, RI at both the dentine and the cement level, there are no significant differences $(\mathrm{RD} / \mathrm{d}=0.661 ; \mathrm{RD} / \mathrm{c}=0.586 ; \mathrm{RSD} / \mathrm{d}=0.755 ; \mathrm{RSD} /$ $c=0.942 ; \mathrm{RI} / \mathrm{d}=0.739 ; \mathrm{RI} / \mathrm{c}=0.985$ ).

Calculation of mean and standard deviation to compare the restoration techniques used showed with no significant difference among the analyzed restoring techniques ( $p>$ 0.05).

They are in agreement with da Veiga et al. which showed that there was no difference in the longevity of direct and indirect composite restorations, regardless of the type of material and type of restored teeth [14].

Another analysis, in which the clinical performances of different types of direct and indirect composite restorations in the posterior teeth were compared, concluded that there was no significant difference between direct and indirect techniques $[15,16]$.

\section{Conclusions}

In order to restore the posterior dental segment, combining nanofilled resin composites for RD and RI with 1-step SE adhesive systems seem to be the best solution/ option.

\section{References}

1.CHALAS $\mathrm{R}$ et al. Composite inlays as a modern way of posterior restorations in the dental arch - Pol J Public Health. 2014; 124(2): 99102.

2. TORABZADEH H et al. Fracture Resistance of Teeth Restored with Direct and Indirect Composite Restorations J ournal of Dentistry, Tehran University of Medical Sciences, 2013;10(5).

3. DEJ AK B, MLOTKOWSKI A. A comparison of stresses in molar teeth restored with inlays and direct restorations, including polymerization shrinkage of composite resin and tooth loading during mastication. Dent Mater. 2015 Mar;31(3):e77-87.

4. CORREA NLR, BORGES AL, GUIMARAES HB, ALMEIDA ER, POSKUS LT, SILVA EM. Marginal integrity of restorations produced with a model composite based on polyhedral oligomeric silsesquioxane (POSS).J Appl Oral Sci. 2015 Oct; 23(5):450-8. 
5. SHIM JS, LEE JS, LEE JY, CHOI YJ, SHIN SW, RYU J J Effect of software version and parameter settings on the marginal and internal adaptation of crowns fabricated with the CAD/CAM system. J Appl Oral Sci. 2015 Oct; 23(5):515-22.

6. DHINGRA V. TANEJA S. KUMAR M. Influence of Fiber Inserts, Type of Composite, and Gingival Margin Location on the Microleakage in Class II Resin Composite Restorations. Operative Dentistry, 2014, 39(1), E9-E15

7. ALHUSSAIN H, ALUMAIRI K, ALZAHRINI M, SALMAN TB, MATHEW. An in vitro study of the effect of blood and saliva contamination on the bond strength of self-etch and total etch adhesive systems to dentine. Clinical Case Reports and Reviews. 2017; Volume 3(3): 1-5 8. ESHRAK $S$ et al. Classification review of dental adhesive systems: from the IV generation to the universal type. Ann Stomatol (Roma). 2017Jan-Mar; 8(1): 1-17.

9. KURTZMAN GM. Case report: Replacing a failing composite using G-Premio Bond and G-aenial Sculpt, Dentistry IQ, March 21, 2016 10. POGGIO C. Influence of dentin pretreatment on bond strength of universal adhesives Acta Biomater Odontol Scand. 2017; 3(1): 30-35. 11. SOUZA EJ , Jr, SOUZA-R MR, ALONSO RC, FREITAS AP, SINHORETI MA, CUNHA LG. Effect of the curing method and composite volume on marginal and internal adaptation of composite restoratives. Oper Dent. 2011;36:231-238.
12. BACIU, S., BERECE, C., FLOREA, A., VOINA TONEA, A., LUCACIU, O., BURDE, A.V., RUSNAC, M., MANOLE, M., SACELEANU, A., MOHAN, A., EARAR, K., CARAIANE, A., Comparison of Two Evaluating Methods for Establishing the Marginal Fit on Four Heat - Pressed Resin Inlays. Rev.Chim.(Bucharest), 69,no.4, 2018, p. 890

13. NEPPELENBROEK KH.The clinical challenge of achieving marginal adaptation in direct and indirect restorations. J Appl Oral Sci. 2015 Sep-Oct; 23(5): 448-449.

14.. da VEIGA AM, CUNHA AC, FERREIRA DM, da SILVA FIDALGO TK, CHIANCA TK, REIS KR, MAIA LC. Longevity of direct and indirect resin composite restorations in permanent posterior teeth: $\mathrm{A}$ systematic review and meta-analysis. J Dent. 2016 Nov;54:1-12.

15.AZEEM RA. Clinical performance of direct versus indirect composite restorations in posterior teeth: A systematic review. J Conserv Dent. 2018 J an-Feb;21(1):2-9.

16. RUBEENA AA, SURESHBABU NM. Clinical performance of direct versus indirect composite restorations in posterior teeth: A systematic review. J Conserv Dent. 2018 Jan-Feb; 21(1): 2-9.

$\overline{\text { Manuscript received:22.01.2018 }}$ 